\section{Conference on Air-raid Shelters}

The Government has now announced its decision on the subject of providing heavily protected shelters against air attack for large numbers of the civil population, and it has come to the conclusion that such a policy is impossible as well as undesirable. There is little doubt that the demand for deep tunnels and 'focal' shelters of the type advocated by the Finsbury Borough Council arose in consequence of statements made by superficial observers in Spain that such shelters were available for many of the inhabitants of Barcelona and other large cities, and that their provision was mainly responsible for the small number of casualties that had resulted from the more recent air raids in Spain. This, too, in spite of the fact that the statements were contradicted in January last by the person in the best position to know, namely, the chief air raid officer in Barcelona. That official was reported in The Times to have said that only about thirty thousand persons out of a total of nearly two millions in Barcelona had such shelters available, and that only about half the population had shelters of any sort, which consisted chiefly of cellars in private houses, and covered trenches. They had learnt from experience the necessity of evacuating the areas that were made special objects of attack, such as the docks, and of clearing the streets and of getting under cover of some sort.

The public was, however, misinformed; and the demand for deep shelters became so insistent that, although the Lord Privy Seal has scarcely concealed his disbelief in the necessity for them, he convened a conference under the chairmanship of Lord Hailey to consider the whole matter. In its report (H.M. Stationery Office, 6d.) the Conference has examined the chief proposals put forward and has rejected all of them, giving half a dozen reasons for the conclusion reached, each one of which would have been sufficient to justify the verdict. The report concludes with a warning against a too ready acceptance of some of the estimates of cost put forward, and by expressing the belief that most British citizens would prefer to count upon less effective protection at their own homes, even if this made no pretence of warding off direct hits or near hits of bombs.

\section{Emergency Preparations in the Event of War}

THE Minister of Health has forwarded to all local authorities concerned in the Government's Evacuation Scheme in England and Wales a communication asking them to work out in detail their plans for the evacuation of school children and others who are to receive priority under the scheme (Ministry of Health Circular 1800. H.M. Stationery Office, 1d.). Enclosed with this communication is a memorandum (Memo. Evacuation No. 4, 3d.) indicating the general lines of the procedure that would be necessary in an emergency and the problems likely to arise, and discussing transport arrangements, arrangements at detraining stations and details of reception, and giving practical advice for householders and others. Authorities are recommended to make full use of all voluntary agencies that might be useful, and it is stated that the Government does not intend that the operation of the scheme should result in any additional burden on the local rates. Another circular has been issued by the Ministry detailing the progress in organization and recruitment of first-aid posts in London. These schemes provide for 131 fixed aid posts, five cleansing stations and thirty-four mobile units. The estimated total of fixed posts required for the County of London is approximately two hundred.

\section{Social Relations of Science}

THE British Association announces a meeting of the new Division for the Social and International Relations of Science to be held at the Royal Institution at 4.30 on Thursday, May 25, by permission of the managers of the Institution. This will be the first public meeting of the Division to be held in London. Prof. Ernest Barker, professor of political science in the University of Cambridge, and Sir Daniel Hall, former chief scientific adviser to the Ministry of Agriculture, are to be the principal speakers, with Sir Richard Gregory, chairman of the Division, in the chair. The object of the meeting is to show how science and society are 'out of gear', and the nature of the task which the Division has undertaken in trying to assist in bringing about an adjustment. Prof. Barker is to speak on "The Impacts of Science on Society", showing the repercussions of scientific discovery and invention upon the social structure. Sir Daniel Hall is to deal with the failure to apply science properly by showing how the application of science to agriculture has been impeded. Sir Richard Gregory will deal with the work of the Division. Primarily, the meeting is intended for workers in every branch of science with the view of securing their interest and co-operation in the work of the Division. It will, however, be open to members of the public and to representatives of organizations interested in the work of the Division. Tickets may be had on application to the Secretary of the British Association, Burlington House, Piccadilly, London, W.1. Another important meeting of the Division is to be held at Manchester in June, when the effects of science upon certain industries will be discussed. Work of the Division at present in hand includes questions of nutrition, population, social psychology, the organization of science and the international relations of science. A committee has also been appointed to report on the world sources of raw materials.

\section{Indirect Rule and the Anthropologist}

As a principle of administration, indirect rule is essentially a system of local government, in theory functioning through local native tribal institutions. Admirable as this principle may be in intention-its object is at once to conduce to fairness and justice in the maintenance of law and order, while educating the native in a sense of civic and political responsibility, and at the same time affording him an opportunity of gradually adapting his institutions to 